\title{
THE AEROBIC BACTERIA ISOLATED FROM USED COSMETIC PRODUCTS AND EVALUATION OF ANTIBIOTIC RESISTANCE
}

\author{
KULLANILMIŞ KOZMETIK ÜRÜNLERDEN IZOLE EDILEN AEROP BAKTERILER VE \\ ANTIBIYYOTIK DIRENCININN DEĞERLENDİRILMESI
}

\begin{abstract}
Ömer AKGÜL ${ }^{1 *}$ (D), Kadir BAKAN² (D)
${ }^{1}$ Van Yüzüncü Y1l University, Faculty of Pharmacy, Department of Pharmaceutical Microbiology, 65080, Van, Turkey,

${ }^{2}$ Van Yüzüncü Y1l University, Instituted of Health Sciences, Department of Pharmaceutical Microbiology, 65080, Van, Turkey
\end{abstract}

\begin{abstract}
Objective: Today, cosmetics sector is one of the thousands of sectors that are inspected within the scope of protection of people's health, preventive health measures, investments made for health rather than illness, and projects made in the name of raising awareness of people without getting sick. Cosmetics need to be produced and maintained in healthy conditions to minimize unwanted effects. The aim of this study is to evaluate the aerobic bacterial contamination of used cosmetic products and the resistance profile (carbapenem and extended-spectrum beta-lactamase) of isolated bacteria.

Material and Method: Five hundred samples were made from used cosmetic products. Microbiological evaluation was performed using culture, biochemical tests, Vitek 2 and polymerase chain reaction (PCR) from the samples.

Result and Discussion: In this study, used cosmetic products were collected from 500 cosmetic users. A total of $101(20.2 \%)$ bacteria were isolated from used cosmetic products $(n=500)$. As a result of identification performed on Vitek 2 device, S. epidermidis (47, 46.5\%), S. hominis (17, 16.8\%), S. aureus (6, 5.9\%), E. coli $(16,15.8 \%)$, K. pneumoniae $(11,10.9 \%)$ and $P$. aeruginosa $(4,4.1 \%)$. Result of phenotypic antibiotic resistance evaluation revealed that 1 isolate was methicillin-resistant $S$. aureus (MRSA) and it was mecA gene positive. It was determined that the isolated 10 gram negative bacteria showed a profile of carbapenem and extendedspectrum beta-lactamase resistance. Only three K. pneumoniae strains were found to carry the bla OXA-48 gene in these isolates. In this study, it was concluded that the cosmetic products may cause serious infections associated with poor personal hygiene, prolonged use, and the bacterial contamination rate of the environment.

Keywords: Contamination, cosmetic product, microbiology
\end{abstract}

\footnotetext{
* Corresponding Author/Sorumlu Yazar: Ömer Akgül e-mail / e-posta: o.akgul@yyu.edu.tr, Phone / Tel.: +904324445065
} 


\section{ÖZ}

Amaç: Günümüzde insanların să̆lı̆̆ını koruma, koruyucu să̆lık tedbirleri, hastalı̆̆a değil să̆lı̆̆a yönelik yapılan yatırımlar ve kişiyi hastalanmadan bilinçlendirme adına yapılan projeler kapsamında denetlenen binlerce sektörden biri de kozmetik sektörüdür. Kozmetiklerin istenmeyen etkilerini en aza indirmek için să̆llklı koşullarda üretilip korunması gerekmektedir. Bu çalışmanın amacı, kullanılan kozmetik ürünlerin aerobik bakteriyel kontaminasyonunu ve izole edilen bakterilerin direnç profilini (karbapenem ve genişletilmiş spektrumlu beta-laktamaz) değerlendirmektir.

Gereç ve Yöntem: Kullanılmış kozmetik ürünlerden beş yüz örnekleme yapıldı. Örneklerden kültür, biyokimyasal testler, Vitek 2 ve polimeraz zincir reaksiyonu (PCR) kullanılarak mikrobiyolojik değerlendirme yapildl.

Sonuç ve Tartışma: Bu çalışmada, 500 kozmetik ürün kullanıcısından, kullanılmış kozmetik ürünler toplandl. Kullanılmış kozmetik ürünlerden $(n=500)$ toplamda $101(\% 20,2)$ bakteri izolasyonu yapıldı. Vitek 2 cihazında gerçekleştirilen identifikason sonucunda izolatların sırasıyla S. epidermidis (47, \%46,5), S. hominis (17, \%16,8), S. aureus (6, \%5,9), E. coli (16, \%15,8), K. pneumoniae (11, \%10,9) ve P. aeruginosa (4, \%4,1) olduğu belirlendi. Fenotipik antibiyotik direncinin değerlendirmesi sonucunda 1 izolatın metisilin dirençli $S$. aureus (MRSA) ve mecA geni pozitif olduğu görüldü. İzole edilen 10 gram negatif bakterinin karbapenem ve genişlemiş-spektrumlu $\beta$-laktamaz direnci profili gösterdiği belirlendi. Bu izolatlarda sadece üç K. pneumoniae suşunun blaOXA-48 geni taşıdığı belirlendi. Bu çalışmada, kozmetik ürün kullanımında kötü kişisel hijyen, uzun kullanımı zaman, and ortamın bakteriyel kontaminasyon oranı ile ilişkili ciddi infeksiyonlara maruz kalınabileceği sonucuna varıldi.

Anahtar Kelimeler: Kontaminasyon, kozmetik ürün, mikrobiyoloji

\section{INTRODUCTION}

The term 'cosmetics' has been derived from the Greek word "kosmetikos," which means skilled in adornment or arrangement in Greek. From past to present, having a beautiful and well-groomed appearance has always been important. Although the sense of beauty varies by the current age and conditions, the use of cosmetic products has always been found the basis of beauty at every age [1]. The very first findings on the use of cosmetics have been found in Egypt. The bowls found in the graves that were found and examined in Egypt during the archeological diggings and cream containers that are still fragrant for years indicate that cosmetics have still been widely used for centuries. It is known that these products, which are used for beauty, are obtained from nice-smelling plants, seeds, and oils, and mainly clergymen prepared them in the past [2].

The Europe Cosmetics Directive ensures that cosmetics are produced to high standards to ensure the safety of consumers. Testing should be carried out to assess the physical and chemical properties and stability of the product, and to find out its microbiological and toxicological results as well [3]. Today, new technologies and systems are being developed in the cosmetic products packaging industry to prevent microbial contamination. However, even if these products are packaged perfectly, contamination can occur for various reasons. Products are exposed to contamination during production, storage, transportation, sales, and service operations. The most microbial contamination occurs in raw materials such as natural substances, carbohydrates, alcohol, glycoside, oil, and protein [4].

The risk of infection that may occur in an eye increases with the contamination of eye cosmetic products used in daily life. Contamination by microorganisms can occur usually in the products that 
highly contact with the eyes during their usages such as contact lenses, cleaning solutions, or soft lenses. Serious infections can be seen in the inner and outer lid of the eye after the use of contaminated eyeliners. It was detected that the contamination occurs especially with gram-negative bacteria [5]. Pseudomonas aeruginosa, which may cause serious infections, can be detected in eye products, especially in eye shadows and mascaras [6]. Although mouthwashes and toothpaste contain antimicrobial preservatives, they are still subject to significant amounts of bacterial and fungal contamination. P. aeruginosa, Staphylococcus aureus, and Candida spp. often perform contamination. It was detected that toothpaste is more frequently contaminated than mouthwashes [7]. Highly contaminated products that are used for skincare may cause skin infection or allergic reactions in users. P. aeruginosa, which is infected from creams, lotions, cellulose bandages, and plaster bandages, may cause serious infections [5]. Shampoos are susceptible to the growth of gram-negative bacteria because of the amount of water they contain. No defect occurs because of contamination, however, changes such as bad smell, different color formation, foaming, and thin layer formation can be observed in products [8]. Shampoos are most contaminated with Enterobacterales and Pseudomonas species [9].

This study aimed to investigate the contamination risk of aerobic bacteria in cosmetic products used by people living in the Van region of Turkey, to evaluate phenotypically and genotypically the antibiotic resistance they have, and to determine their effects on public health.

\section{MATERIAL AND METHOD}

\section{Isolation and Identification of Bacteria, and Antibiogram Test}

Used cosmetic products were collected from 500 cosmetic product users in the Van region of Turkey. The cosmetic products were divided into groups regarding their durations of use (Table 1). The sampling method was determined according to whether the products were liquid, semi-solid, and solid. $1 \mathrm{~mL}$ samples of liquid products and $1 \mathrm{gr}$ samples of semi-solid and solid products were collected in this way, sampling was completed. The samples were inoculated into the medium containing $8.5 \mathrm{~mL}$ of preprepared Brain Heart infusion Broth (BHI, Oxoid, UK) and $0.5 \mathrm{~mL}$ of Tween 80 . The bottles in which growth was detected were inoculated into 5\% sheep-blooded agar base (Acumedia, USA), McConkey Agar (Oxoid, UK), and Eosin Methylene Blue agar (EMB, Oxoid, UK). The cultures were left for incubation at $37{ }^{\circ} \mathrm{C}$ for 72 hours. The colony morphology of the cultures was evaluated. Their biochemical tests such as the Catalase test, Oxidase test, and Gram staining were carried out. Vitek 2 Compact (Biomerieux, USA) system was used for the identification of the bacteria and antibiogram test [10]. Screening of cefoxitin, benzylpenicillin, ampicillin, oxacillin, gentamicin, ciprofloxacin, levofloxacin, moxifloxacin, inducible clindamycin resistance, erythromycin, clindamycin, quinupristin/ dalfopristin, linezolid, vancomycin, tetracycline, tigecycline, nitrofurantoin, rifampin, trimethoprim/ sulfamethoxazole was used for phenotypically antibiotic susceptibility analysis and evaluation was 
made according to minimal inhibitory concentration ( $\mathrm{MIC}, \mu \mathrm{g} / \mathrm{mL}$ ) value [11]. The identified bacteria were stored at $-20^{\circ} \mathrm{C}$.

Table 1. Used cosmetic products and their distribution by the duration of use.

\begin{tabular}{|l|c|c|c|c|}
\hline \multirow{2}{*}{$\begin{array}{c}\text { Used Cosmetic } \\
\text { Products }\end{array}$} & \multicolumn{4}{c|}{ Duration of Use of Cosmetic Products } \\
\cline { 2 - 5 } & 3 Months & 6 Months & 9 Months & 12 Months \\
\hline Hand and Face Cream & 18 & 7 & 9 & 3 \\
\hline Sunscreen & 21 & 13 & 8 & 4 \\
\hline Toothpaste & 9 & 7 & 4 & 2 \\
\hline Hand and Body Lotion & 11 & 14 & 8 & 8 \\
\hline Tonics & 17 & 8 & 4 & 4 \\
\hline Masks & 14 & 10 & 6 & 6 \\
\hline Serums & 5 & 7 & 9 & 7 \\
\hline Body Oils & 17 & 12 & 7 & 14 \\
\hline Hair Products & 8 & 5 & 6 & 3 \\
\hline Lipsticks & 21 & 12 & 11 & 2 \\
\hline Mascaras & 7 & 7 & 8 & 16 \\
\hline Cleansing Gels & 13 & 11 & 7 & 4 \\
\hline Foundations & 19 & 9 & 6 & 1 \\
\hline Makeup Pencils & 8 & 6 & 8 & \\
\hline
\end{tabular}

\section{Bacterial DNA Extraction and Amplification}

Bacterial DNA extraction was performed at the Pharmaceutical Microbiology Laboratory of the Faculty of Pharmacy, Van Yüzüncü Y1l University. The bacteria stored at $-20{ }^{\circ} \mathrm{C}$ were thawed at room temperature. They were inoculated into Trypton Soy Agar (Acumedia, USA) and were incubated at 37 ${ }^{\circ} \mathrm{C}$ for 24 hours. Then, the DNAs of Escherichia coli, P. aeruginosa, Klebsiella pneumoniae, and $S$. aureus strains were obtained using G-SpinTM Total DNA Extraction kit (IntronBio, Korea) protocol. The bacterial DNA samples were stored at $-20^{\circ} \mathrm{C}$.

Bacterial DNA amplification was carried out by taking Sahebnasagh et al. [12] and Poirel et al. [13] studies as references. $5 \mu \mathrm{L}$ of template DNA, $200 \mu \mathrm{M}$ of deoxynucleotide triphosphate (Life Technologies) each, 1,5 U Taq DNA polymerase (abm, Canada), buffer (20 mMTris-HCL, $50 \mathrm{mM}$ $\mathrm{KCL}$ ), and $3 \mathrm{mM} \mathrm{MgCL} 2$ (Biotools) were adjusted to be a $50 \mu \mathrm{L}$ of final solution for PCR. The PCR conditions were arranged to be $2 \mathrm{~min}$ at $94{ }^{\circ} \mathrm{C}, 20 \mathrm{sec}$ at $94{ }^{\circ} \mathrm{C}$ (denaturation), $45 \mathrm{sec}$ at $54{ }^{\circ} \mathrm{C}$ (annealing), $60 \mathrm{sec}$ at $72{ }^{\circ} \mathrm{C}$ (extension), $5 \mathrm{~min}$ at $72{ }^{\circ} \mathrm{C}$. Amplicon products were run at Thermo EC300XL2 electrophoresis device at 100 Volts for 1,5 hours on 1,5\% agarose gel. Amplicons were visualized using Bio-Print- ST4 (Vilber Lourmant, France) device. DNA amplification of the isolated and identified bacteria was performed using the reference primers in Table 2. 
Table 2. Reference oligonucleotide sequences used in the study.

\begin{tabular}{|l|l|c|c|}
\hline Gene Region & Primer Sequence & Base Size & Reference \\
\hline$m e c A$ & $\begin{array}{l}\text { F: 5'-CCAATTCCACATTGTTTCGGTCATA-3' } \\
\text { R: 5'-GTAGAAATGACTGAACGTCCGATAA-3' }\end{array}$ & $310 \mathrm{bp}$ & [12] \\
\hline blaoxA-48 & $\begin{array}{l}\text { F: 5'-GCGTGGTTAAGGATGAACAC-3' } \\
\text { R: 5'-CATCAAGTTCAACCCAACCG -3' }\end{array}$ & $438 \mathrm{bp}$ & {$[13]$} \\
\hline bla $_{I M P}$ & $\begin{array}{l}\text { F: 5'-GGAATAGAGTGGCTTAATTCTC-3' } \\
\text { R: 5'-GGTTTAATAAAACAACCACC-3' }\end{array}$ & $232 \mathrm{bp}$ & {$[13]$} \\
\hline
\end{tabular}

\section{RESULT AND DISCUSSION}

The products may be contaminated when applying by users and especially it may be observed that unwanted microorganisms may contaminate the products at varying rates [3]. These products, which are contaminated by the time they are used for the first time, may contain microorganisms that pose serious risks on public health and cause concern for health such as E. coli, Citrobacter freundii, $P$. aeruginosa, and S. aureus. Cosmetic products containing these microorganisms may pose a serious threat of infection after they are applied especially on the mouth and eye region [4]. In several studies, it was emphasized that cosmetic products that contained S. aureus and E. coli were important potential pathogen carriers $[15,16]$. Although we are protected from infections, serious infections may occur because of microorganisms passing through cuts and scratches on the skin along with ineffective sanitation practices during the use of products. Staphylococcus species are commensal organisms found on the skin. Especially S. aureus, S. epidermidis, S. saprophyticus, S. haemolyticus, S. cohnii, and $S$. capitis were isolated from mascaras, eyeliners, and lip glosses [3]. S. capitis is found commonly in the facial region and plays a role in the contamination of cosmetic products. S. capitis takes part in the formation of septicemia in premature children and endocarditis infections in individuals in whom pacemakers are implanted [17, 18]. S. haemolyticus exists in the axilla, perineum, and umbilical region. The agent, which causes hospital infections, is known to play a serious role especially in urinary tract infections [19].

In a study conducted in the UK, microbiological contamination rates were analyzed in a total of 467 products including lip glosses (107), mascaras (93), eyeliners (92), lip liners (96), and makeup sponges (79). It was reported that the analyzed products were contaminated with 48 bacteria. The highest contamination was reported to be in the makeup sponges. Staphylococcus, Micrococcus, and Enterobactererales species were found to play an important role in the contamination [3]. It was observed in some studies that Salmonella, S. aureus, S. epidermidis, E. coli, and P. aeruginosa emerged from mascaras, eyeliners, and face powders [6, 14]. Lip glosses and lipsticks were found to serve as important carriers in terms of Escherichia hermannii, S. aureus, Bacillus cereus, and Enterobacter species [20]. S. epidermidis, Bacillus spp., E. coli, and S. aureus species were found to be the most common bacteria in the mascara samples. After the identification carried out on lipsticks, S. aureus was 
reported to have a significant role in their contamination. In the eyeshadow and foundation samples, Streptococcus and Bacillus species were reported to be more common [15]. Jung et al. [21] investigated the presence of bacterial contamination in lip glosses and lipsticks that were used by 16 dentists. They revealed contamination in which P. putida, Bacillus spp., Staphylococcus salivarius, Enterococcus faecalis, and S. aureus were effective. In a study conducted in Turkey, the presence of bacteria that cause microbiological contamination in cosmetic products (Mouthwash, tooth cleaning powder, and teeth pad) used for oral and dental health was investigated. Gram-negative bacteria and Coagulase negative Staphylococci (CNS) agents were reported to play a significant role in the contamination of all three cosmetic products. In the tooth-cleaning powder, it was revealed that the contamination with $E$. coli was more than it was in the other products [22]. In our study, microbiological contamination levels were investigated in a total of 100 used cosmetic products including 53 lipsticks, 24 mascaras, and 23 makeup pencils. CNS (12 S. epidermidis and 2 S. hominis), 2 S. aureus, and 3 E. coli were isolated from the cosmetic products. The fact that $S$. aureus and E. coli strains are associated with serious infections in the isolated products showed that the risk was significant. It was observed that people should be careful during the use of products. Regarding the oral health, in consequence of the analysis of bacterial contamination observed in the 22 used tubes of toothpaste, 9 S. epidermidis, 4 S. hominis, 1 S. aureus, and $1 \mathrm{~K}$. pneumoniae were isolated. It was observed that users could be exposed to important microorganisms in tubes of toothpaste.

In a study Lundov and Zachariae [23] conducted between 2005 and 2008, they reported that the highest strain isolated from 24 different used cosmetic products was P. aeruginosa (\%42). In a study conducted in Iran, it was reported that the highest rate of contamination in 24 used moisturizing creams and hand and face creams belonged to gram-positive bacilli (54\%). The second-most common bacterium was revealed to be $S$. aureus (38\%). The E. coli incidence in used cosmetic creams was reported to be $13 \%$. The concentration of other gram-negative bacteria in used creams was found to be only $8 \%$ [24]. Bacterial contamination in eye and skin cosmetic products used in beauty salons was observed to be quite high. Regarding the used skin cosmetic products (loose and cream powder), it was observed that Streptococcus (32\%), Pseudomonas (23\%), Acinetobacter (19\%), Bacillus (11\%), Staphylococcus (6\%), and E. coli (4\%) were isolated the most. It was reported that Streptococcus (25\%), Pseudomonas (24\%), Acinetobacter (10\%), Staphylococcus (10\%), Bacillus (8\%), E. coli (8\%), Salmonella (4\%), Klebsiella (4\%), and Citrobacter (2\%) were isolated the most in the used eye cosmetic products (mascara and eyeliner) [14]. Janetos et al. [25] reported that they detected 120 bacterial contaminations in their study on personal care products between 2002 and 2016. They revealed that 120 isolates were Burkholderia cepacia (n: 65), Enterobacter gergoviae (n: 30), and P. aeruginosa (n: 25), respectively. In another study, gram-positive bacilli, S. aureus, and gram-negative bacteria (excluding E. coli) were assessed in used and unused cosmetic creams. Microorganism contamination rates in the unused creams $(38 \%, 25 \%$, 
and $0 \%$, respectively) were determined to be lower when compared with the ones in the used creams $(54 \%, 38 \%$, and $8 \%)$ [26]. In our study, a total of 101 (20.2\%) bacteria were isolated from used cosmetic products $(\mathrm{n}=500)$. As a result of the identification conducted at Vitek 2 system, these isolates were determined to be Staphylococcus epidermidis ( $\mathrm{n}=47,46.5 \%)$, Staphylococcus hominis $(\mathrm{n}=17,16.8 \%)$, S. aureus $(\mathrm{n}=6,5.9 \%)$, E. coli $(\mathrm{n}=16,15.8 \%)$, . pneumoniae $(\mathrm{n}=11,10.9 \%)$, and $P$. aeruginosa $(\mathrm{n}=4$, $4.1 \%$ ). The bacteria causing contamination were evaluated in 37 hand and face creams, 36 masks, and 50 body oils. Gram-positive and gram-negative bacteria isolated from these cosmetic products were determined to be 11 S. epidermidis, 2 S. hominis, 1 S. aureus, 5 E. coli, 3 K. pneumoniae, and $1 P$. aeruginosa, respectively. Bacterial contamination assessment of 47 cleansing gels, 41 hand and body lotions, 33 tonics, 28 serums, and 22 hair products were carried out and a total of 16 medically important bacteria were isolated, including 4 S. epidermidis, 7 S. hominis, 1 S. aureus, 2 E. coli, 1 K. pneumoniae, and $1 P$. aeruginosa. Foundation is an important cosmetic product that women use extensively in facial makeup. In our study, 5 E. coli, 4 K. pneumoniae, and $1 P$. aeruginosa were isolated from the foundation products collected from 38 different individuals. During the first months of use, contamination in the foundation products were observed to be minimal. However, gram-negative bacterial contamination began to be more detected from the 3rd month (Table 3).

Skin is a delicate, sensitive, and vulnerable protective organ, which covers the outer part of our bodies. At the same time, the skin acts as a shield, which protects our bodies against pathogenic bacteria [27]. It is strongly recommended that the skin not be exposed to direct sunlight for a long time and continuously, and sunscreen be used to prevent wrinkles and skin cancers [27, 28]. Sunscreens are the most common cosmetic products used to protect the skin effectively. However, sunscreens are not sterile $[29,30]$. It is not possible to see the microorganism loads that these non-sterile products have with the naked eye. Especially, it was also reported that significant pathogens were playing a role in the contamination in sunscreens [30, 31]. Haftabaradaran et al. [26] revealed the contamination risk occurred in a sample of 90 sunscreens in a study. After the isolation carried out six months later, it was reported that $S$. aureus strains, $P$. aeruginosa strains, and coliform bacteria were identified at a rate of $28.8 \%, 18.8 \%$, and $8.8 \%$, respectively. 46 used sunscreens from different brands were included in this study. It was observed that gram-positive bacteria activity was more effective in the first three months and then gram-negative activity increased later. In the first three months, while 11 S. epidermidis, $2 \mathrm{~S}$. hominis, and $1 S$. aureus were isolated out of 21 sunscreens; only $2 \mathrm{~K}$. pneumoniae, 1 P. aeruginosa, and $1 E$. coli were isolated out of the sunscreens that were used for 12 months (Table 3). It was revealed that as the duration of use of sunscreens increased, the incidence of bacterial density that causes significant human infections also increased. It was thought that different contamination rates in sunscreens were affected by user habits, duration of use, and the contamination of the environment. 
Table 3. Distribution of gram-positive and gram-negative bacteria isolated from some used cosmetic products in different time intervals

\begin{tabular}{|c|c|c|c|c|c|c|c|}
\hline $\begin{array}{l}\text { Used } \\
\text { Cosmetic } \\
\text { Products (n) }\end{array}$ & Date (Month) & S. epidermidis & $\begin{array}{l}\text { S. } \\
\text { hominis }\end{array}$ & S. aureus & E. coli & K. pneumoniae & P. aeruginosa \\
\hline \multirow{4}{*}{$\begin{array}{l}\text { Hand and } \\
\text { face creams } \\
(n=37)\end{array}$} & 3 & - & - & - & - & - & - \\
\hline & 6 & 1 & - & - & 2 & - & 1 \\
\hline & 9 & 3 & & 1 & - & 1 & - \\
\hline & 12 & 2 & - & - & - & - & - \\
\hline \multirow{4}{*}{$\begin{array}{l}\text { Masks } \\
(n=36)\end{array}$} & 3 & - & - & - & - & - & - \\
\hline & 6 & - & - & - & - & 2 & - \\
\hline & 9 & 2 & - & - & 1 & - & - \\
\hline & 12 & - & 1 & - & - & - & - \\
\hline \multirow{4}{*}{$\begin{array}{l}\text { Body oils } \\
(n=50)\end{array}$} & 3 & - & - & - & 1 & - & - \\
\hline & 6 & 1 & - & - & - & - & - \\
\hline & 9 & 1 & - & - & - & - & - \\
\hline & 12 & 1 & 1 & - & - & - & - \\
\hline \multirow{4}{*}{$\begin{array}{l}\text { Cleansing } \\
\text { gels } \\
(n=47)\end{array}$} & 3 & - & - & - & - & - & - \\
\hline & 6 & - & 1 & - & - & - & - \\
\hline & 9 & 1 & 1 & 1 & 1 & - & - \\
\hline & 12 & - & - & - & - & - & - \\
\hline \multirow{4}{*}{$\begin{array}{l}\text { Hand and } \\
\text { body } \\
\text { lotions } \\
(n=41)\end{array}$} & 3 & - & - & - & - & - & - \\
\hline & 6 & 1 & 1 & - & - & - & - \\
\hline & 9 & - & - & - & - & - & - \\
\hline & 12 & - & - & - & - & - & - \\
\hline \multirow{4}{*}{$\begin{array}{l}\text { Tonics } \\
(n=33)\end{array}$} & 3 & - & - & - & - & - & - \\
\hline & 6 & - & - & - & - & - & - \\
\hline & 9 & - & 1 & - & - & - & - \\
\hline & 12 & 1 & - & - & - & - & - \\
\hline \multirow{4}{*}{$\begin{array}{l}\text { Serums } \\
(n=28)\end{array}$} & 3 & - & - & - & - & - & - \\
\hline & 6 & - & 1 & - & - & - & - \\
\hline & 9 & - & - & - & - & - & - \\
\hline & 12 & - & - & - & - & - & - \\
\hline \multirow{4}{*}{$\begin{array}{l}\text { Hair } \\
\text { products } \\
(n=22)\end{array}$} & 3 & - & - & - & - & - & - \\
\hline & 6 & - & 2 & - & 1 & 1 & - \\
\hline & 9 & 1 & - & - & - & - & 1 \\
\hline & 12 & - & - & - & - & - & - \\
\hline \multirow{4}{*}{$\begin{array}{l}\text { Foundations } \\
(n=38)\end{array}$} & 3 & - & - & - & 1 & 3 & - \\
\hline & 6 & - & - & - & 1 & 1 & 1 \\
\hline & 9 & - & - & - & 3 & - & - \\
\hline & 12 & - & - & - & - & - & - \\
\hline \multirow{4}{*}{$\begin{array}{l}\text { Sunscreens } \\
(n=46)\end{array}$} & 3 & 11 & 2 & 1 & - & - & - \\
\hline & 6 & - & - & - & - & - & - \\
\hline & 9 & - & - & - & - & - & - \\
\hline & 12 & - & - & - & 1 & 2 & 1 \\
\hline
\end{tabular}

In the articles studied around the world, no information on the antibiotic resistance characteristics of bacteria isolated from used cosmetic products could be reached. In our study, antibiotic susceptibility test results of the bacteria were evaluated both phenotypically and genotypically. Antibiotic susceptibility test results of the bacteria obtained from the automated Vitek 2 system were given in Table 4 and Table 5. S. aureus isolates were found to show the highest antibiotic resistance to benzylpenicillin and gentamicin.

The phenotypic antibiotic evaluation showed that 1 isolate was MRSA. Vancomycin resistance was seen in none of the $S$. aureus isolates. Only one of the $S$. aureus isolates was revealed to show 
intermediate susceptibility to benzylpenicillin. It was detected that the highest resistance in the $S$. epidermidis isolates was to benzylpenicillin and ampicillin antibiotics. None of the CNS isolates were observed to have resistance to methicillin and vancomycin. The phenotypic evaluation revealed that the isolates showed intermediate antibiotic resistance to ampicillin, tetracycline, and tigecycline, respectively. S. hominis isolates were found to show the highest antibiotic resistance to gentamicin and benzylpenicillin. None of the isolates were found to show resistance to methicillin and vancomycin. It was revealed that the $S$. hominis isolates showed the highest intermediate antibiotic resistance to trimethoprim/sulfamethoxazole (SXT). E. coli isolates were found to show the highest antibiotic resistance to SXT, ampicillin, and gentamicin antibiotics phenotypically.

Table 4. Antibiotic resistance characteristics of gram-positive bacteria isolated from used cosmetic products.

\begin{tabular}{|c|c|c|c|c|c|c|c|c|c|}
\hline & \multicolumn{3}{|c|}{ S. aureus $(\mathrm{n}=6)$} & \multicolumn{3}{|c|}{ S. epidermidis $(\mathrm{n}=47)$} & \multicolumn{3}{|c|}{ S. hominis $(\mathrm{n}=17)$} \\
\hline Antibiotics (MIC, $\mu \mathrm{g} / \mathrm{mL})$ & $\mathrm{R}$ & I & $\mathrm{S}$ & $\mathrm{R}$ & I & $\mathrm{S}$ & $\mathrm{R}$ & I & $\mathrm{S}$ \\
\hline Cefoxitin Screening & 1 & - & 5 & - & - & 47 & - & - & 17 \\
\hline Benzylpenicillin & 3 & 1 & 2 & 26 & - & 21 & 12 & - & 5 \\
\hline Ampicillin & 2 & - & 4 & 17 & 3 & 27 & 3 & - & 14 \\
\hline Oxacillin & 1 & - & 5 & - & - & 47 & - & - & 17 \\
\hline Gentamicin & 3 & - & 3 & 5 & - & 42 & 13 & 1 & 3 \\
\hline Ciprofloxacin & 2 & - & 4 & 1 & - & 46 & 7 & - & 10 \\
\hline Levofloxacin & 1 & - & 5 & 9 & - & 38 & 1 & - & 16 \\
\hline Moxifloxacin & 1 & - & 5 & 1 & - & 46 & - & - & 17 \\
\hline Inducible Clindamycin Resistance & 1 & - & 5 & - & - & 47 & - & - & 17 \\
\hline Erythromycin & 1 & - & 5 & 5 & - & 42 & 8 & - & 9 \\
\hline Clindamycin & 1 & - & 5 & - & - & 47 & - & - & 17 \\
\hline $\mathrm{Q} / \mathrm{D}^{*}$ & 2 & - & 4 & 1 & - & 46 & 2 & - & 15 \\
\hline Linezolid & - & - & 6 & 2 & - & 45 & 1 & - & 16 \\
\hline Vancomycin & - & - & 6 & - & - & 47 & - & - & 17 \\
\hline Tetracycline & 1 & - & 5 & 17 & 2 & 28 & 6 & - & 11 \\
\hline Tigecycline & 2 & - & 4 & 3 & 1 & 44 & 1 & - & 16 \\
\hline Nitrofurantoin & - & - & 6 & 7 & - & 40 & - & - & 17 \\
\hline Rifampin & - & - & 6 & 11 & - & 36 & - & - & 17 \\
\hline SXT* $^{*}$ & - & - & 6 & 15 & - & 31 & 3 & 3 & 11 \\
\hline
\end{tabular}

* Q/D: Quinupristin/ Dalfopristin; SXT: Trimethoprim/ Sulfamethoxazole; R: Resistant; I: Intermediate Susceptible; S: Susceptible; MIC: Minimal Inhibitory Concentration $(\mu \mathrm{g} / \mathrm{mL})$.

It was revealed that $2 E$. coli isolates showed extended-spectrum $\beta$-lactamase resistance. $1 E$. coli strain was found to have carbapenem resistance. As a result of the phenotypic evaluation, it was identified that $K$. pneumoniae isolates developed the highest resistance to SXT. 5 K. pneumoniae isolates were found to have extended-spectrum $\beta$-lactamase resistance. Carbapenem resistance was detected in $1 \mathrm{~K}$. pneumoniae strain. It was revealed that the highest resistance in $P$. aeruginosa isolates was to SXT. 
Table 5. Antibiotic resistance characteristics of gram-negative bacteria isolated from used cosmetic products.

\begin{tabular}{|c|c|c|c|c|c|c|c|c|c|}
\hline \multirow[b]{2}{*}{$\begin{array}{l}\text { Antibiotics } \\
(\mathrm{MIC}, \mu \mathrm{g} / \mathrm{mL})\end{array}$} & \multicolumn{3}{|c|}{ E. $\operatorname{coli}(\mathrm{n}=16)$} & \multicolumn{3}{|c|}{ K. pneumoniae $(\mathrm{n}=11)$} & \multicolumn{3}{|c|}{ P. aeruginosa $(\mathrm{n}=4)$} \\
\hline & $\mathrm{R}$ & I & $\mathrm{S}$ & $\mathrm{R}$ & I & $\mathrm{S}$ & $\mathrm{R}$ & I & $\mathrm{S}$ \\
\hline Ampicillin & 5 & - & 11 & 5 & - & 6 & - & - & 4 \\
\hline AMC* & 3 & - & 13 & 5 & - & 6 & - & - & 4 \\
\hline $\mathrm{P} / \mathrm{T}^{*}$ & 3 & - & 13 & 3 & - & 8 & - & - & 4 \\
\hline Cefazolin & 2 & - & 14 & 5 & - & 6 & - & - & 4 \\
\hline Cefuroxime & 2 & - & 14 & 5 & - & 6 & - & - & 4 \\
\hline Cefuroxime Axetil & 2 & - & 14 & 5 & - & 6 & - & - & 4 \\
\hline Cefoxitin & 1 & - & 15 & 2 & - & 9 & - & - & 4 \\
\hline Ceftazidime & 2 & - & 13 & 5 & - & 6 & - & - & 4 \\
\hline Ceftriaxone & 3 & - & 13 & 5 & - & 6 & 1 & - & 3 \\
\hline Cefepime & 1 & - & 15 & 1 & - & 10 & 1 & - & 3 \\
\hline Ertapenem & 1 & - & 16 & 1 & - & 10 & 1 & - & 3 \\
\hline Imipenem & 1 & - & 16 & 1 & - & 10 & 1 & - & 3 \\
\hline Meropenem & - & - & 16 & 1 & - & 10 & 1 & - & 3 \\
\hline Amikacin & 2 & - & 14 & - & - & 11 & - & - & 4 \\
\hline Gentamicin & 5 & - & 11 & - & - & 11 & - & - & 4 \\
\hline Ciprofloxacin & 3 & - & 13 & 5 & - & 6 & 1 & - & 3 \\
\hline Levofloxacin & 1 & - & 15 & 5 & - & 6 & - & - & 4 \\
\hline Tigecycline & 1 & - & 15 & - & 3 & 8 & - & - & 4 \\
\hline Colistin & - & - & 16 & - & - & 11 & - & - & 4 \\
\hline SXT* & 8 & - & 8 & 7 & - & 4 & 2 & - & 2 \\
\hline
\end{tabular}

* AMC: Amoxicillin/ Clavulanic Acid; P/T: Piperacillin/ Tazobactam; SXT: Trimethoprim/ Sulfamethoxazole; R: Resistant; I: Intermediate Susceptible; S: Susceptible; MIC: Minimal Inhibitory Concentration $(\mu \mathrm{g} / \mathrm{mL})$.

Only one of the $P$. aeruginosa strains was found to show carbapenem resistance. It was revealed that extended-spectrum $\beta$-lactamase resistance existed in none of the $P$. aeruginosa isolates. It was concluded that revealing antibiotic resistance profiles of bacteria isolated from cosmetic products may play an important role in eliminating the risk that may occur on human health.

It was found that the resistance genes of the bacteria isolated after microbiological contamination assessment in used cosmetic products had not been analyzed. The literature was reviewed regarding our region and it was observed that no detailed information on the antibiotic resistance of bacteria isolated from cosmetic products and the analysis of carried gene regions was presented. Only 1 MRSA isolate was isolated in gram-positive bacteria. The analysis of MRSA isolate performed by PCR revealed that it was a mecA gene carrier. It was analyzed in terms of bla $a_{O A-48}$ and $b l a_{I M P}$ genes of gramnegative bacteria. $3 \mathrm{~K}$. pneumoniae isolates were found to carry the bla ${ }_{O X A-48}$ gene (Fig. 1). None of the isolated gram-negative bacteria was found to carry the $\operatorname{bla}_{I M P}$ gene. It was observed that the bacteria carrying important antibiotic genes could contaminate the cosmetic products that are used. It was determined that the use of contaminated cosmetic products can form a significant potential threat to public health for the emergence of flora bacteria with a resistance gene. 


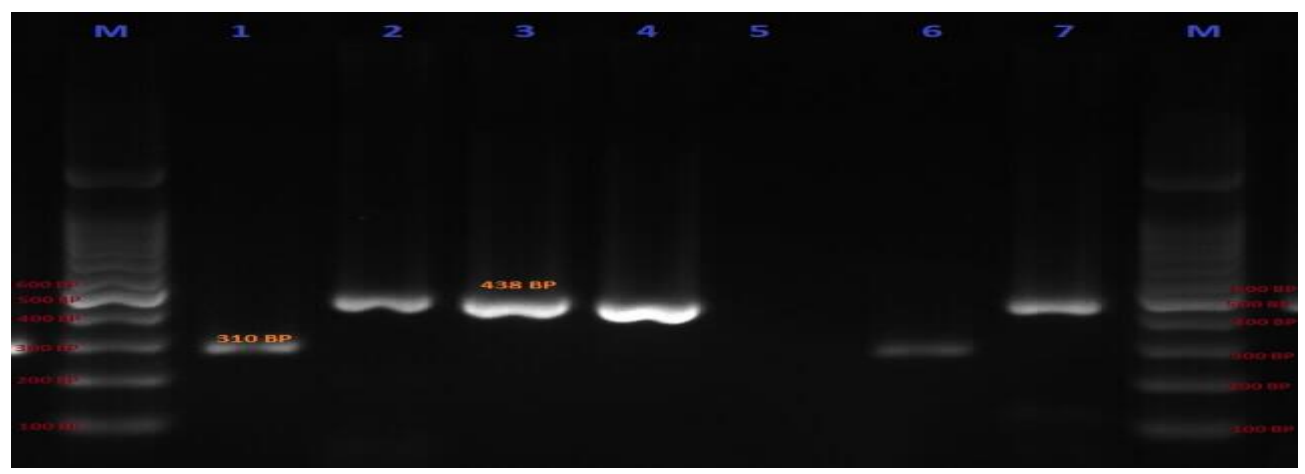

Figure 1. M: $100 \mathrm{bp}$ marker; 1: mecA gene positive $S$. aureus; 2,3,4,: bla OXA-48 $_{\text {genes }}$ positive K. pneumoniae isolates; 5. Negative kontrol; 6: Positive control of MRSA;

7: Positive control of bla OXA-48 $_{\text {positive K. pneumoniae. }}$

In conclusion, this study revealed that the bacterial profile in contaminated used cosmetic products might vary by personal features and conditions, duration of use, and environmental factors. It was observed that the risk that the bacteria isolated from used cosmetic products could cause significant community-acquired infections. It was found that the antibiotic resistance profiles of the bacterial agents isolated from personal care products varied and they were resistant to methicillin, carbapenem, and extended-spectrum $\beta$-lactamase, which could be difficult to treat. For this reason, it is concluded that paying no attention to personal hygiene, duration of use, the environment of the cosmetic product, and using products that do not belong to you may cause serious infections.

\section{AUTHOR CONTRIBUTIONS}

Conception: Ö.A.; Design: Ö.A., K.B.; Supervision: Ö.A., K.B.; Resources: Ö.A., K.B.; Materials: K.B.; Data collection and/or processing: $\ddot{O} . A ., K . B$; Analysis and/or interpretation: $\ddot{O} . A$., K.B.; Literature search: $̈ . A$., K.B.; Writing manuscript: $\ddot{O} . A . ;$ Critical review: $\ddot{O} . A$.; Other: -

\section{CONFLICT OF INTEREST}

The authors declare no conflict of interest.

\section{REFERENCES}

1. Çarıkçı, A., Uçar, F., Yalçın, H. T. (2008). Kozmetik ürünlerde bakteriyal ve fungal kompozisyonun klasik yöntemler ve pcr yöntemi kullanılarak saptanması. Elektronik Mikrobiyoloji Dergisi, 6(01), 1-16.

2. Çomoğlu, T. (2012). Kozmetikler. Marmara Pharmaceutical Journal, 16, 1 - 8 . 
3. Bashir, A., Lambert, P. (2019). Microbiological study of used cosmetic products: highlighting possible impact on consumer health. Journal of Applied Microbiology, 128(2), 598 - 605.

4. Güven, N., Onurdağ, F. K. (2014). İlaç, kozmetik ve gıda ürünlerinde kullanılan bazı koruyucuların antimikrobiyal ve antibiyofilm etkisinin araştırılması. Mikrobiyoloji Bülteni, $48(1), 94-105$.

5. Kıvanç, M. (2012). Kozmetik ürünlerde mikrobiyel kontaminasyon. 2. Kozmetik Kongresi, 1719 Şubat, Antalya, p. $1-15$.

6. Abdelaziz, A. A., Ashour, M. S., Hefni, H., el-Tayeb, O. M. (1989). Microbial contamination of cosmetics and personal care items in Egypt eye shadows, mascaras and face creams. Journal of Clinical Pharmacy Therapeutics, 14(1), 21 - 28.

7. Ashour, M. S. E., Hefni, H., El-Tayeb, O. M., Abdelaziz, A. A. (1987). Microbial contamination of cosmetics and personal care items in egypt-1-contamination of toothpastes and mouthwashes. Journal of the Society of Cosmetic Chemists, 38, $441-435$.

8. Özalp, M. (1998). Kozmetik ürünlerde görülen mikrobiyolojik kontaminasyonlar. Türkiye Klinikleri Kozmetoloji Dergisi, 1(3), 167 - 176.

9. Brannan, D. K. (1996). Cosmetic preservation. Cosmetics and Toiletries, 111, $69-83$.

10. Fatima, N. (2014). Bacteriological evaluation and comparison of unused branded and nonbranded cosmetic products available in Jazan region of Saud1 Arabia. Journal of Microbial World, 16(1-2), $57-67$.

11. EUCAST. (2018). Breakpoint tables for interpretation of MIC's and zone diameters. Version 8.0. January 2018. European Committee on Antimicrobial Susceptibility Testing.

12. Sahebnasagh, R., Saderı, H., Owlia, P. (2014). The prevalence of resistance to methicillin in staphylococcus aureus strains isolated from patients by PCR method for detection of mecA and nuc genes. Iranian Journal of Public Health, 43(1), 84 - 92.

13. Poirel, L., Walsh, T. R., Cuvillier, V., Nordmann, P. (2011). Multiplex PCR for detection of acquired carbapenemase genes. Diagnostic Microbiology and Infectious Disease, 70(1), 119 123.

14. Eldesoukey, R. M. M., Alqhtani, B. S., Alqhtani, A. S., Alqhtani, A. H., Alqhtani, A. M. (2016). Comparative microbiological study between traditional and modern cosmetics in Saudi Arabia. Enzyme Engineering, 5(2), 1 - 5.

15. Onurdağ, F. K., Özgen, S., Abbasoğlu, D. (2010). Microbiological investigation of used cosmetic samples. Hacettepe University Journal of the Faculty of Pharmacy, 30(1), 1 - 16.

16. Dadashi, L., Dehghanzadeh, R. (2016). Investigating incidence of bacterial and fungal contamination in shared cosmetic kits available in the women beauty salons. Health Promotion Perspectives, 6(3): 159 - 163.

17. Wang, S. M., Liu, C. C., Tseng, H. W., Yang, Y. J., Lin, C. H., Huang, A. H., Wu, Y. H. (1999). Staphylococcus capitis bacteremia of very low birth weight premature infants at neonatal 
intensive care units: clinical significance and antimicrobial susceptibility. Journal of Microbiology, Immunology, and Infection, 32(1), 26 - 32.

18. Cone, L. A., Sontz, E. M., Wilson, J. W., Mitruka, S. N. (2005). Staphylococcus capitis endocarditis due to a transvenous endocardial pacemaker infection: case report and review of Staphylococcus capitis endocarditis. International Journal of Infectious Diseases, 9(6), 335 339.

19. Fischetti, V. A., Novick, R. P., Ferretti, J. J., Portnoy, D. A., Rood, J. I. (2006). Gram-positive pathogens, ASM Press, Washington USA, p. 432.

20. Babalola, M. O., Eze, M. (2015). Microbiological quality and characterization of potential pathogens associated with selected brands of commercial cosmetic products in Nigeria. British Microbiology Research Journal, 9(5), 1 - 17.

21. Jung, I., Kim, J., Yoo, Y., Yoo, J., Park, B., Choi, E. (2019). A pilot study of occupational exposure to pathogenic microorganisms through lip cosmetics among dental hygienists. Journal of Occupational Health, 61(4), 297 - 304.

22. Altan, S. (2010). Master's Thesis. Ağız ve Diş Preparatlarında Farmasötik ve Mikrobiyolojik Kalite Kontrol Çalışmaları. Mersin University, Mersin, Turkey.

23. Lundov, M. D., Zachariae, C. (2008). Recalls of microbiologically contaminated cosmetics in EU from 2005 to May 2008. International Journal of Cosmetic Science, 30(6), 471 - 474.

24. Behravan, J., Bazzaz, F., Malaekeh, P. (2005). Survey of bacteriological contamination of cosmetic creams in Iran (2000). International Journal of Dermatology, 44(6), 482 - 485.

25. Janetos, T. M., Akintilo, L., XU, S. (2018). Overview of high-risk food and drug administration recalls for cosmetics and personal care products from 2002 to 2016. Journal of Cosmetic Dermatology, 18(5). doi: 10.1111/jocd.12824. Online ahead of print.

26. Haftbaradaran, B., Abedi, D., Jalali, M., Bagherinejad, M. R. (2014). Microbial quality survey of sunscreen products in Iranian market. Advanced Biomedical Research, 3, 1- 14.

27. Templeton, K., Gripentrog, E., Hellwig, T. (2012). Shining the light on sunscreen. US Pharmacist, 37(4), 36 - 39.

28. Jemec, G. B., Renneberg, J., Wulf, H. C. (1997). Microbiology of sunscreens in use. Dermatosen in Beruf und Umwelt, 45(6), 275 - 277.

29. Baird, R. M., Bloomfield, S. F. (1996). Microbial quality assurance in cosmetics, toiletries and non-sterile pharmaceuticals, Taylor and Francis Groups, CRC Press, London, p. 272.

30. Kabara, J. J., Orth, D. (1997). Preservative-free and self-preserving cosmetics and drugs: principles and practices, CRC Press, New York, p. 287.

31. Wedderburn, D. L. (1964). Preservation of emulsions against microbial attack. Advances in Pharmaceutical Sciences, 1, 195 - 268. 